\title{
Remote-Sensing-Based Analysis of Spatiotemporal Variation of ET and Related Parameters in Xilingol Steppe, China
}

\author{
Qiaofeng Zhang, ${ }^{1,2,}$, Liping Di²*, Guixiang Liu ${ }^{3}$, Liying Guo², Hongbo Yu${ }^{1}$ \\ ${ }^{1}$ College of Geographical Science, Inner Mongolia Normal University, Hohhot, Inner Mongolia, 010022, China \\ ${ }^{2}$ Center for Spatial Information Science and Systems, George Mason University, Fairfax, VA, 22031, USA \\ ${ }^{3}$ Grassland Research Institute, Chinese Academy of Agricultural Sciences, Hohhot, Inner Mongolia, 010010, China
}

Received: 28 April 2020

Accepted: 3 November 2020

\begin{abstract}
Evapotranspiration (ET), as the main ecological water consumer, is crucial to assess the ecological water budget and dry conditions in arid and semi-arid areas. The objective of this study was to characterize the spatiotemporal variations of ET and determine the major parameters affecting ET by using remote sensing data and climate data at annual and seasonal scales in Xilingol steppe, China. The results of this study showed that the annual ET gradually reduced from northeast to southwest in the Xilingol steppe, with the values fluctuating around $200 \mathrm{~mm}$ per year during 2000-2014. The seasonal value of the spatially averaged ET was in reducing order from summer, fall, and winter to spring, accounting for approximately $35 \%, 23 \%, 22 \%$, and $20 \%$ of the annual ET, respectively. The largest ET appeared in summer in meadow steppe, typical steppe, and sandy vegetation steppe, while in the desert steppe, it occurred in winter, accounting for $39 \%$ of the annual ET. Precipitation and NDVI are the major parameters positively affecting ET in spring, summer, and fall. However, in winter, ET was positively correlated with temperature and negatively correlated with precipitation. The results indicated that the spatiotemporal characteristics and the affecting parameters of the actual ET vary seasonally and that the characteristics of the annual ET are mainly determined by the growing season (spring-fall). Moreover, vegetation growth is directly correlated with ET and sunshine hours rather than other parameters. Combining with the natural conditions, the conclusions can be deduced that the dry conditions in the meadow and typical steppes are probably caused by uneven precipitation distribution and high ET demands during the growing season, while the low annual precipitation combined with high winter evaporation is the main reason for water scarcity in the desert steppe.
\end{abstract}

Keywords: evapotranspiration (ET), MOD16A2, NDVI, meteorological factors, Xilingol steppe

*e-mail: ldi@gmu.edu 


\section{Introduction}

Evapotranspiration (ET) is the sum of transpiration from living vegetation surfaces plus evaporation from open water bodies, wetlands, bare soil, and snow cover [1-3]. ET is the main process of water and energy exchange among atmosphere, hydrosphere, soil and biosphere. It is an important link between ecological process and hydrological process. The ET process consumes more than $50 \%$ of the net solar radiation at the Earth's surface [4,5], and the accompanying latent heat flux helps to control surface temperature with a cooling effect [5]. ET can also affect precipitation [6], as near $60 \%$ of the total terrestrial precipitation is returned to the atmosphere through the ET process [7]. Therefore, ET is one of the most fundamental factors necessary for understanding and monitoring the ecological water demands and water-related natural disasters in arid and semiarid areas. In particular, during drought disasters, the significance of ET is amplified because ET continues to deplete the limited remaining water supplies in the soil [1].

Arid and semi-arid area is one of the most ecologically fragile areas in the world. Nowadays, most of the area faces desertification risk due to the severe drought [8] and many measures have been reported to prevent losses caused by the climate changes [9, 10]. In order to make better policies and actions for desertification mitigation and climate change resilience, it is scientifically important and policy relevant to understand the spatio-temporal characteristics and behaviors of ET in the arid and semi-arid area. This study attempted to provide such an understanding by conducting remote-sensing-based analysis of spatiotemporal variation of ET and related parameters in Xilingol steppe, China.

The Xilingol steppe in northern China is part of the Eurasian steppe and is a typical arid and semiarid temperate grassland region [11] with diverse grassland types and abundant forage plant resources [12]. This steppe is one of the vital ecological indicators and animal husbandry production bases in northern China [13]. Since 1950's, drought disasters [14] and grassland degradation [15] in this region have been severe due to the impacts of climate changes and human activities. Precipitation is the main water source and ET is the main water consumer in Xilingol steppe. Thus, characterizing the spatiotemporal variations of ET is of great significance to assess the water budget and water consumption in different grassland types. Many studies have been focused on the ecological and environmental changes in the Xilingol steppe, especially on the variations of precipitation, temperature and vegetation coverage and the relationships among them [16, 17]. Some studies also paid attention to grassland area monitoring and grass yield estimations

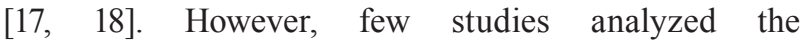
spatiotemporal variations of vegetation conditions based on ET [19].
The reasons for the above situation lie in two aspects: on the one hand, there are many factors that affect the ET process, such as vegetation and weather parameters, management and environmental conditions [2]. Therefore, the ET models, such as the famous Penman equations based on a comprehensive theory of aerodynamic and energy balance [20], the Penman-Monteith model [21], S-SEBI [22], SEBAL $[23,24]$, and SEBS [25] models, are usually very complex, need to consider many complex processes and parameters, and require many relevant data as the model inputs, which are difficult to obtain. On the other hand, the traditional ET models are usually based insitu data, which is difficult to form a long time-series product for monitoring and analyzing long-term ET characteristics over a large area [19]. Furthermore, the physical and biological diversities in the land surface over a large geographic area make it difficult to directly apply traditional local-scale ET methods to solve the regional-scale problem. Recent advances in satellite remote-sensing-based ET measurements have made the consistent and timely ET measures over a large geographic area feasible and practical $[3,26]$. One of the most popular satellite-based ET products is MOD16A2 from the U.S. National Aeronautics and Space Administration (NASA), which is currently the only global-scale ET product with high spatiotemporal resolution and long data series. The MOD16A2 product has been widely used in many regions [27-29]. However, the product has been used less in grassland areas and is especially rare in the Xilingol Steppe.

At present, the existing literatures generally concluded that large evaporation is the main reason for the dry condition in the west part of Xilingol steppe $[30,31]$. The conclusion was all based on weather station records of pan evaporation and temperature, suggesting both increased from east to west. However, the pan evaporation measured at weather stations is not the actual ET from the natural land surface but likely the maximum evaporation of the free water body in the area because of the unlimited supply of water in the evaporating pan [2]. In arid and semiarid regions, such as Xilingol steppe, the actual ET is mainly limited by both water and energy, while the pan evaporation at the weather stations is not limited by water but energy. Thus, the spatio-temporal characteristics of pan evaporation might be totally different from those of the actual ET. Due to the diversity of grassland types in the Xilingol and the complexity of ET process, there are still great uncertainties about the characteristics of actual ET. The uncertainties have become the bottleneck for hydrological, ecological, climatic and environmental research in the region. In order to mitigate the frequent drought and grassland degradation conditions in Xilingol steppe, it is in urgent needs to characterize the spatiotemporal characteristics of actual ET in different grassland types and reveal the impacts of ecological water allocation on vegetation. This study attempts to meet the urgent needs by analyzing 
the monthly MOD16A2 data product to understand the spatiotemporal variations of actual ET in different grassland types at annual and seasonal scales from 2000 to 2014. The results from this study could be used by environmentalists, policymakers, farmers and herdsmen to better manage water resources and make more effective remedial measures to mitigate climate change impacts on the vegetation in Xilingol steppe.

The rest of the paper was structured in the following way: Section 2 showed the material and methods used in this study; Section 3 presented the results and discussion; the paper concluded at Section 4.

\section{Material and Methods}

\section{Study Area}

The Xilingol steppe is located in the central part of Inner Mongolia in northern China (Fig. 1) and lies

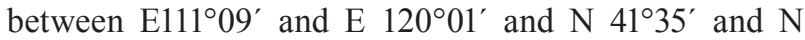
$46^{\circ} 46^{\prime}$. The steppe has a total area of approximately $202,600 \mathrm{~km}^{2}$ with an available grassland area of $180,000 \mathrm{~km}^{2}$ [31]. Influenced by the East Asian monsoon, this region has a temperate arid and semiarid continental climate. The annual precipitation decreases from $380 \mathrm{~mm}$ in the northeast to $120 \mathrm{~mm}$ in the southwest (Fig. 2a). However, the annual mean temperature increases from approximately $0^{\circ} \mathrm{C}$ in the northeast to $6^{\circ} \mathrm{C}$ in the southwest (Fig. 2b). Due to the southwestward decreasing gradient of precipitation and the southwestward increasing gradient of temperature, the growing-season mean NDVI value decreases from northeast to southwest (Fig. 2c). The vegetation types are spatially well differentiated and divided into four vegetation types, namely, meadow steppe, typical steppe, sandy vegetation, and desert steppe (Fig. 1) [32, 33]. In this study, the spatial distribution of different grassland types was extracted from the vegetation map of Inner Mongolia at a scale of 1:1,000,000.

\section{Data Sources and Processing}

\section{Remote Sensing Data}

Because NASA only produced and released the monthly MOD16A2 data product for the period from 2000 to 2014 and the aim of this study was to characterize the ET variations at both annual and seasonal scales, the study period was set from 2000 to 2014. Both the monthly MOD16A2 ET and MOD13A3 NDVI datasets with a $1000 \mathrm{~m}$ spatial resolution were downloaded from the University of Montana (http:// www.ntsg.umt.edu) and NASA LP DAAC (https:// ladsweb.modaps.eosdis.nasa.gov/), respectively. MODIS Re-projection Tools [34] was used to convert the downloaded data from HDF format to TIFF format and the SIN projection to the Albers Equal Area projection with the WGS84 ellipsoid. The image mosaic was also completed at the same time.

The pixel values for the monthly MOD16A2 ET are the sum of ET within the composite days, so the annual

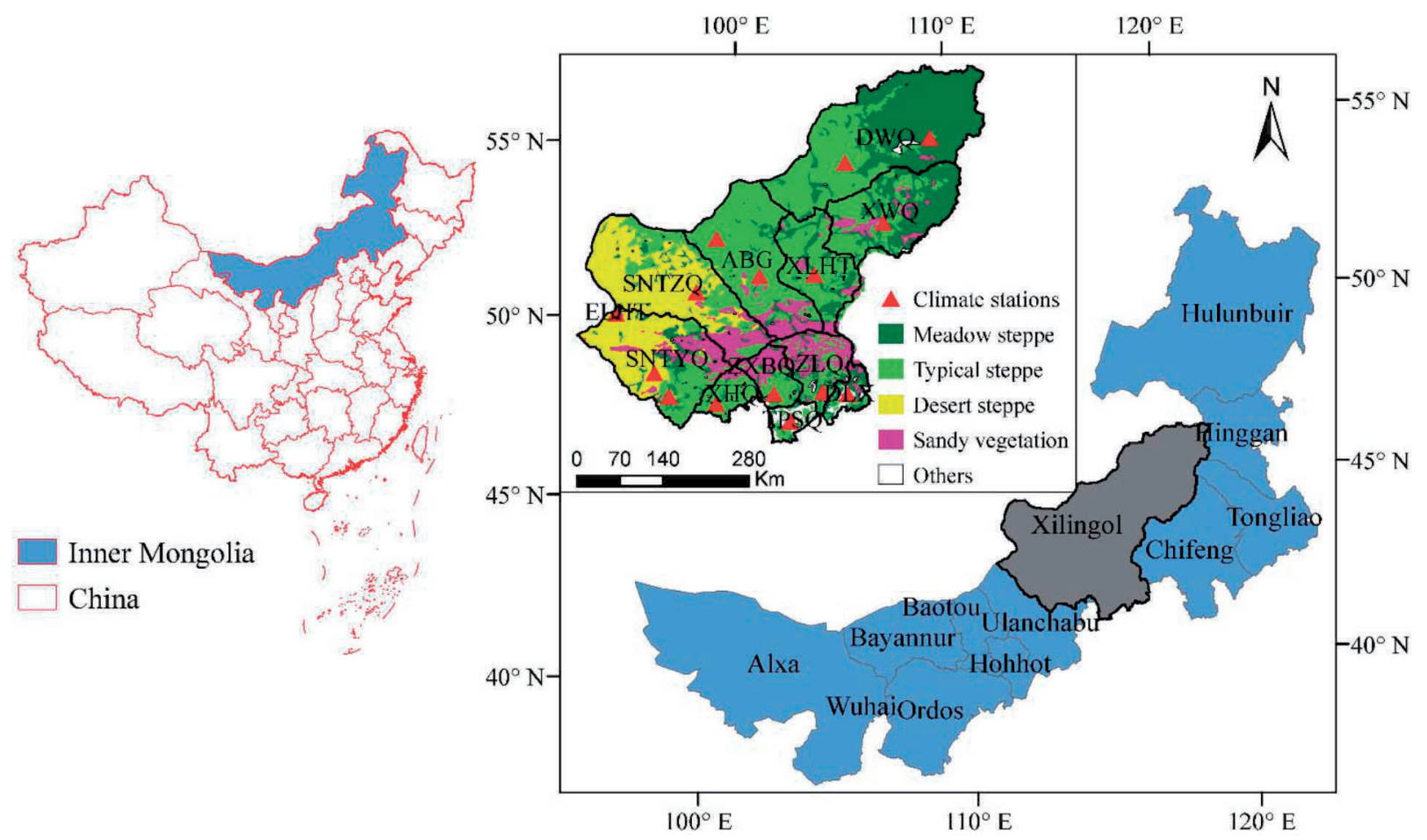

Fig. 1. Location of study area, spatial distribution of climate stations, and grassland types in the Xilingol Steppe. 

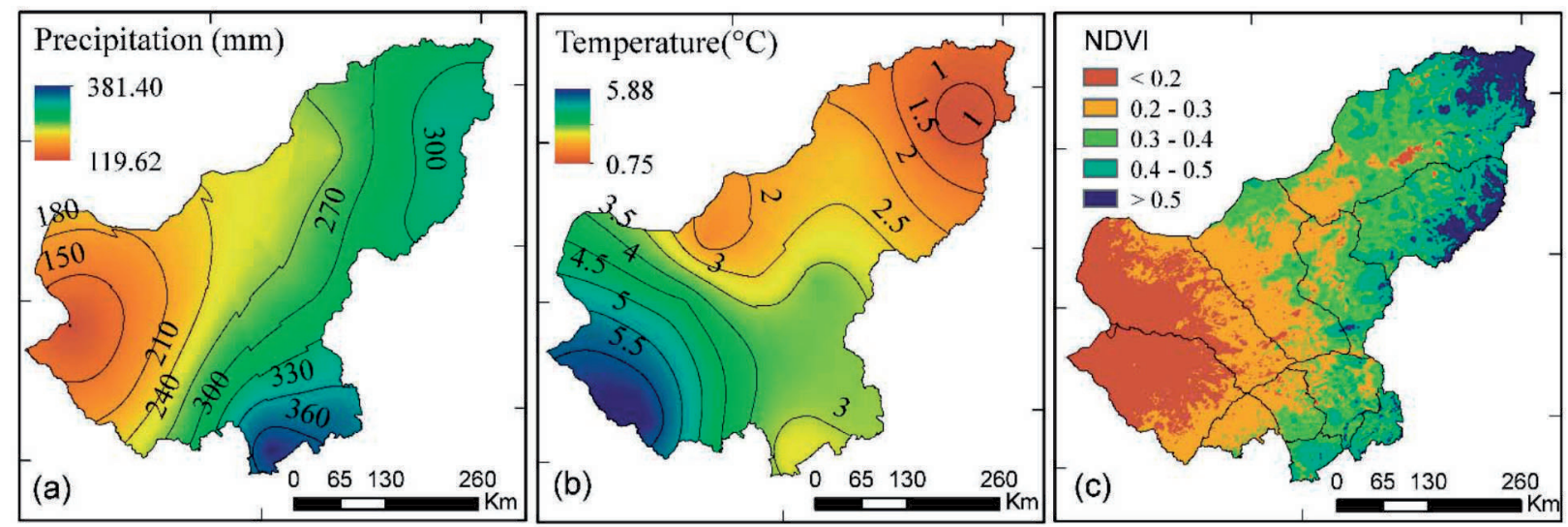

Fig. 2. Annual mean precipitation a), annual mean temperature b), and growing-season mean NDVI c) from 2000-2014.

ET was calculated from the sum of twelve months within one year. The seasonal ET of spring (March-May), summer (June-August), fall (September-November), and winter (December and January-February of the next year) were generated separately through the sum of respective months. Because most vegetation withered in Xilingol or was covered by snow in winter [35], the annual NDVI was defined as the mean of the growing-season NDVI from March to November, and the seasonal NDVI averages for spring (March-May), summer (June-August) and fall (September-November) were calculated for the respective months. All the processed datasets were clipped by the boundaries of Xilingol and grassland types.

\section{Climate Data}

The annual and seasonal climate data, including precipitation, mean temperature, wind speed, sunshine hours, water vapor pressure and relative humidity, were calculated from the monthly data, which were acquired from the China Weather Information Center (http:// data.cma.cn) and the Inner Mongolia Weather Bureau, and these parameters were measured at 15 climate stations in the Xilingol steppe (Fig. 1). The coordinate information from the climate stations was applied to extract the corresponding values of the ET and NDVI images at each station, and the relationships between ET and NDVI and climate parameters were analyzed at all the investigated scales.

\section{Methods \\ Pearson Correlation Analysis}

The Pearson correlation analysis (Eq. 1) and highest partial correlation analysis (Eq. 2) were utilized to explore the relationships between MOD16A2 ET and NDVI and climate factors.

$$
r_{x y}=\frac{\sum_{i=1}^{n}\left[\left(x_{i}-\bar{x}\right)\left(y_{i}-\bar{y}\right)\right]}{\sqrt{\sum_{i=1}^{n}\left(x_{i}-\bar{x}\right)^{2} \sum_{i=1}^{n}\left(y_{i}-\bar{y}\right)^{2}}}
$$

...where $r_{x y}$ is the Pearson correlation coefficient between variables $\mathrm{x}$ and $\mathrm{y}$, with a value ranging from -1 to 1 (a larger absolute value indicates a stronger correlation); $i$ represents the year from 1 to 15 in the study period; $n$ represents the total period (i.e., 15 years in this study); $x_{i}$ is the MOD16A2 ET data in the $i^{\text {th }}$ year; $y_{i}$ is the annual or seasonal NDVI, precipitation, mean temperature, wind speed, sunshine hours, water vapor pressure or relative humidity in the $i^{\text {th }}$ year; $\bar{x}$ represents the mean MOD16A2 ET; and $\bar{y}$ is the mean value of the annual or seasonal NDVI, precipitation, mean temperature, wind speed, sunshine hours, water vapor pressure or relative humidity from 2000 to 2014.

The highest partial correlation analysis is to fix $m-2$ variables among $m$ variables and study only the correlation of the other two variables (there are eight variables in this study, including ET, NDVI, precipitation, water vapor pressure, relative humidity, mean temperature, wind speed, and sunshine hours). To directly reveal the response characteristics of NDVI to ET and climate factors, the highest partial correlation was applied to analyze the net correlation between NDVI and each element. In equation (2), $r_{x y}$ has the same meaning as in equation $1, r_{x y}$ is the highest partial correlation coefficient between $\mathrm{x}$ and $\mathrm{y}$, and so on.

$$
\begin{gathered}
r_{x y .}=\frac{-c_{x y}}{\sqrt{c_{x x} c_{y y}}} \text {, where } C=R^{-1}=\left[\begin{array}{cccc}
c_{x x} & c_{x y} & \cdots & c_{x m} \\
c_{y x} & c_{y y} & \cdots & c_{y m} \\
\vdots & \vdots & \vdots & \vdots \\
c_{m x} & c_{m y} & \cdots & c_{m m}
\end{array}\right], \\
\text { and } R=\left[\begin{array}{cccc}
r_{x x} & r_{x y} & \cdots & r_{x m} \\
r_{y x} & r_{y y} & \cdots & r_{y m} \\
\vdots & \vdots & \vdots & \vdots \\
r_{m x} & r_{m y} & \cdots & r_{m m}
\end{array}\right]
\end{gathered}
$$

The significance tests of correlation and partial correlation coefficients were performed based on 
the $t$ test formulations in Obilor et al. [36] and Zhang et al. [37], respectively. According to the results, the significance values were divided into extremely significant $(P<0.01)$, significant $(P<0.05)$ and nonsignificant $(P>0.05)$. The classification of significance test for linear regression analysis is the same for the Pearson correlation analysis.

\section{Linear Regression Analysis}

A linear regression analysis was utilized to analyze the temporal trends of ET variations, and the linear model is expressed as Eq. (3).

$$
y=a+b x
$$

...where $\mathrm{y}$ is the annual ET value from 2000 to 2014; $x$ is the year from 2000 to 2014; and $a$ and $b$ are the intercept and slope of the regression line, respectively, with the latter being calculated by Eq. (4).

$$
b=\frac{\sum(x-\bar{x})(y-\bar{y})}{\sum(x-\bar{x})^{2}}
$$

...where, $\bar{x}$ is the mean value of the years, and $\bar{y}$ is the mean value of ET during 2000-2014. When $b>0$, ET is increasing, and when $b<0$, it is decreasing.

The $t$ test was used to determine whether the change was significant or not, which was calculated as follows (Eq. 5):

$$
t=\frac{b \times \sqrt{\sum(x-\bar{x})^{2}}}{\sqrt{\frac{Q}{n-2}}}
$$

...where $Q=\sum_{i=1}^{n}\left(y_{i}-\hat{y}_{i}\right)^{2}$ is the sum of the error squares, $y_{i}$ is the annual ET value in the $i^{\text {th }}$ year (and $\hat{y}_{i}$ is its regression value), and $\mathrm{n}=15$ in this paper.

In addition, $R^{2}=\frac{U}{Q+U}$ is the coefficient of determination (where $U=\sum_{i=1}^{n}\left(\hat{y}_{i}-\bar{y}_{i}\right)^{2}$ is regression sum of squares), which is used to reflect the proportion of the regression sum of squares to the total sum of squares, and the larger the value is and the closer it is to 1 , the better the model fit is.

In this study, both the Pearson correlation analysis and linear regression analysis were used to explore the annual and seasonal relationships between MOD16A2 ET and NDVI and climate parameters at the site scale. Fig. 3 shows the flowchart of the methodology adopted in this study.

\section{Results and Discussion}

\section{Annual Variations in ET at the Xilingol Steppe}

Fig. 4 displays the spatial distribution of the annual ET from 2000 to 2014. The southwestward decreasing trend of the annual ET is consistent with that of the annual mean precipitation and NDVI but is different from the distribution of the annual mean temperature (Fig. 2), which is consistent with the results found by Chen et al. [38], demonstrating that precipitation and

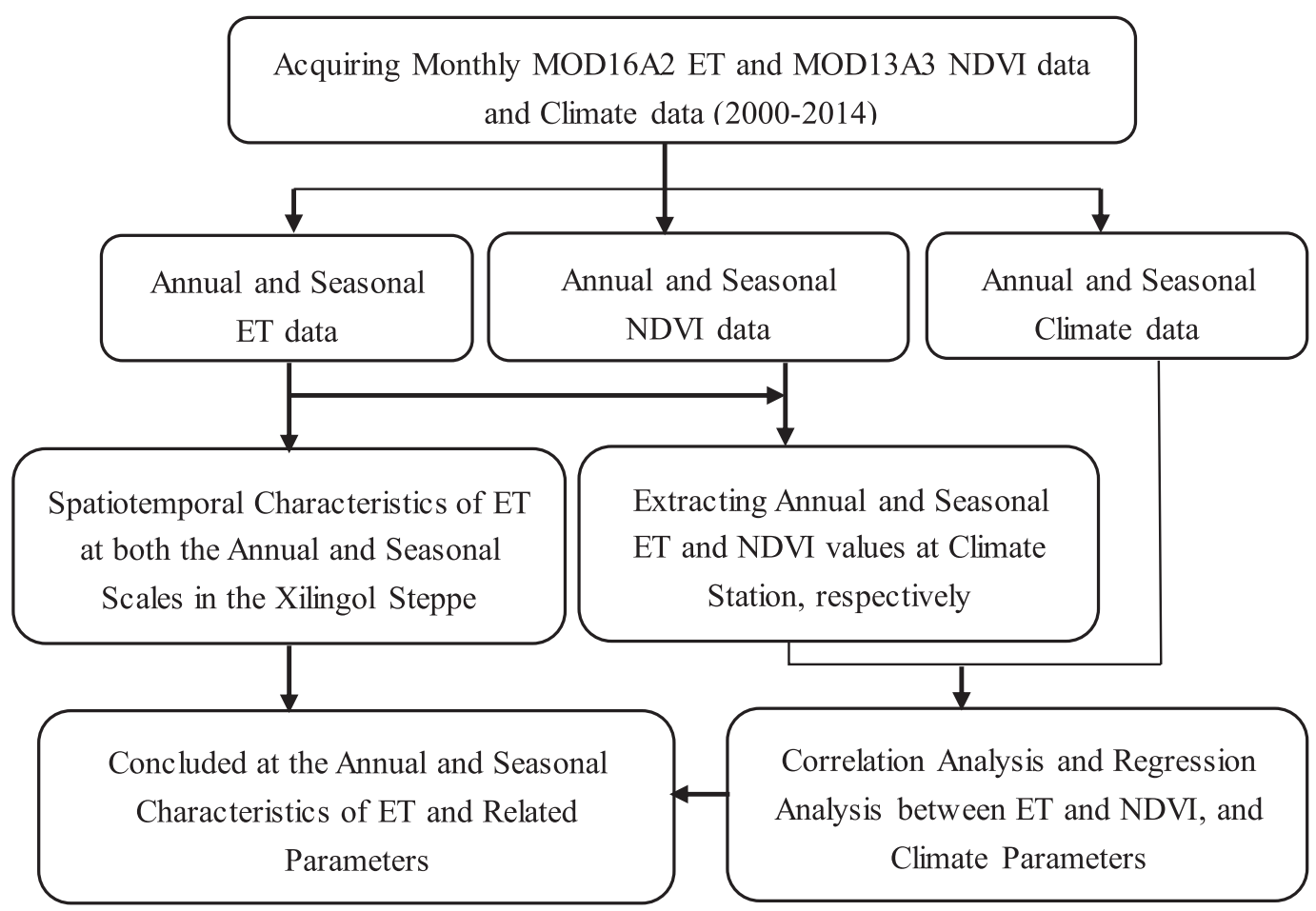

Fig. 3. Flowchart of the methodology. 
NDVI play important driving roles in the ET process, and mean temperature is a converse factor at the annual scale.

To intuitively analyze the ET changes in various grassland types, the spatially averaged ET values were extracted and presented in Table 1, which shows that the annual ET varied from $186.59 \mathrm{~mm}$ to $247.51 \mathrm{~mm}$ in the Xilingol steppe during 2000-2014, and the averaged ET is $218.21 \mathrm{~mm}$; meanwhile, the annual ET in the meadow steppe, typical steppe, sandy vegetation and desert steppe ranged from $216.90 \mathrm{~mm}$ to $297.37 \mathrm{~mm}$, from $178.62 \mathrm{~mm}$ to $248.18 \mathrm{~mm}$, from $180.02 \mathrm{~mm}$ to $247.41 \mathrm{~mm}$ and from $121.60 \mathrm{~mm}$ to $170.20 \mathrm{~mm}$, respectively, with the averaged ET of $268.49 \mathrm{~mm}, 210.56 \mathrm{~mm}, 206.63 \mathrm{~mm}$ and $145.12 \mathrm{~mm}$, respectively. It is proved that the annual ET in the meadow steppe is largest, followed by the typical steppe and sandy vegetation, while the spatially averaged ET in the desert steppe is the smallest. A linear trend analysis revealed that the annual ET in the meadow steppe, typical steppe, and Xilingol steppe all showed increasing trends with the slope of $1.61 / \mathrm{yr}, 1.14 / \mathrm{yr}$ and $0.94 / \mathrm{yr}$, respectively; while in the sandy vegetation and desert steppe, all showed decreasing trends with the slope of $-0.04 / \mathrm{yr}$ and -0.22 / $\mathrm{yr}$, respectively (Table 1); but significant tests indicate that none of the changes were significant.

As an important component of water balance, ET is a crucial parameter in drought monitoring. For example, CWSI (Crop Water Shortage Index) [39, 40] is a drought monitoring index constructed by $\frac{E T}{P E T}$ with the formula of $C W S I=1-\frac{E T}{P E T}$, where the smaller the is, the closer the CWSI is to 1 and the severer drought degree (PET is potential ET, it represents the maximum ET of a consistent underlying surface with an abundant water supply). The spatial distribution of the annual ET (Fig. 4) is contrary to the annual PET (Fig. 5a), thus, the $\frac{E T}{P E T}$ is decreasing from east to west (Fig. 5b) and the degree of aridity is gradually aggravating [41]. In addition, the annual PET ranges from 1082.21 $\mathrm{mm}$ in the northeast to $1844.47 \mathrm{~mm}$ in the southwest (Fig. 5a), and the annual ET is far below the annual PET. The huge difference shows that, in arid and semiarid areas, due to the constraints of water supply, the actual ET is far below the PET and the droughts are frequently happened [14, 35, 42]. The highly positive correlation between the annual $\frac{E T}{P E T}$ and the annual precipitation ( $\mathrm{r}=0.83, P<0.01$ ) (Fig. $5 \mathrm{c}$ ) further shows that the precipitation, as the main water source, is much lower than the requirement of evaporation, which is the main reason for the dry conditions in this region. Because the smaller the ET is, the severer the aridity is, the increasing trends of the annual ET in the meadow steppe, typical steppe, and the whole Xilingol steppe indicate that the aridity is mitigated in these areas, while the decreasing trends of the annual ET in the sandy vegetation and desert steppes imply that the aridity is aggravated in the two steppes.

Table 1. Spatially averaged ET in different grassland types in Xilingol from 2000 to 2014 (mm/Year).

\begin{tabular}{|c|c|c|c|c|c|}
\hline Year & Meadow steppe & Typical steppe & Sandy vegetation & Desert steppe & Xilingol steppe \\
\hline 2000 & 249.80 & 189.66 & 198.56 & 141.31 & 202.07 \\
\hline 2001 & 267.63 & 198.73 & 201.20 & 141.94 & 211.37 \\
\hline 2002 & 274.79 & 228.08 & 211.96 & 161.26 & 230.63 \\
\hline 2003 & 282.45 & 242.05 & 247.41 & 170.20 & 245.05 \\
\hline 2004 & 274.37 & 217.12 & 223.13 & 149.63 & 225.58 \\
\hline 2005 & 272.44 & 193.00 & 183.14 & 121.60 & 204.86 \\
\hline 2006 & 256.18 & 195.04 & 198.77 & 134.50 & 205.43 \\
\hline 2007 & 216.90 & 180.83 & 186.98 & 144.69 & 187.83 \\
\hline 2008 & 285.06 & 225.04 & 211.19 & 147.83 & 230.41 \\
\hline 2009 & 227.49 & 178.62 & 180.02 & 128.28 & 186.59 \\
\hline 2010 & 263.26 & 211.97 & 210.31 & 144.61 & 217.86 \\
\hline 2011 & 267.97 & 199.41 & 196.91 & 136.05 & 210.38 \\
\hline 2012 & 297.37 & 248.18 & 224.17 & 162.59 & 247.51 \\
\hline 2013 & 297.05 & 230.50 & 219.85 & 148.50 & 238.42 \\
\hline 2014 & 294.66 & 220.21 & 205.87 & 143.76 & 229.15 \\
\hline Slope & 1.61 & 1.14 & -0.04 & -0.22 & 0.94 \\
\hline Mean & 268.49 & 210.56 & 206.63 & 145.12 & 218.21 \\
\hline
\end{tabular}



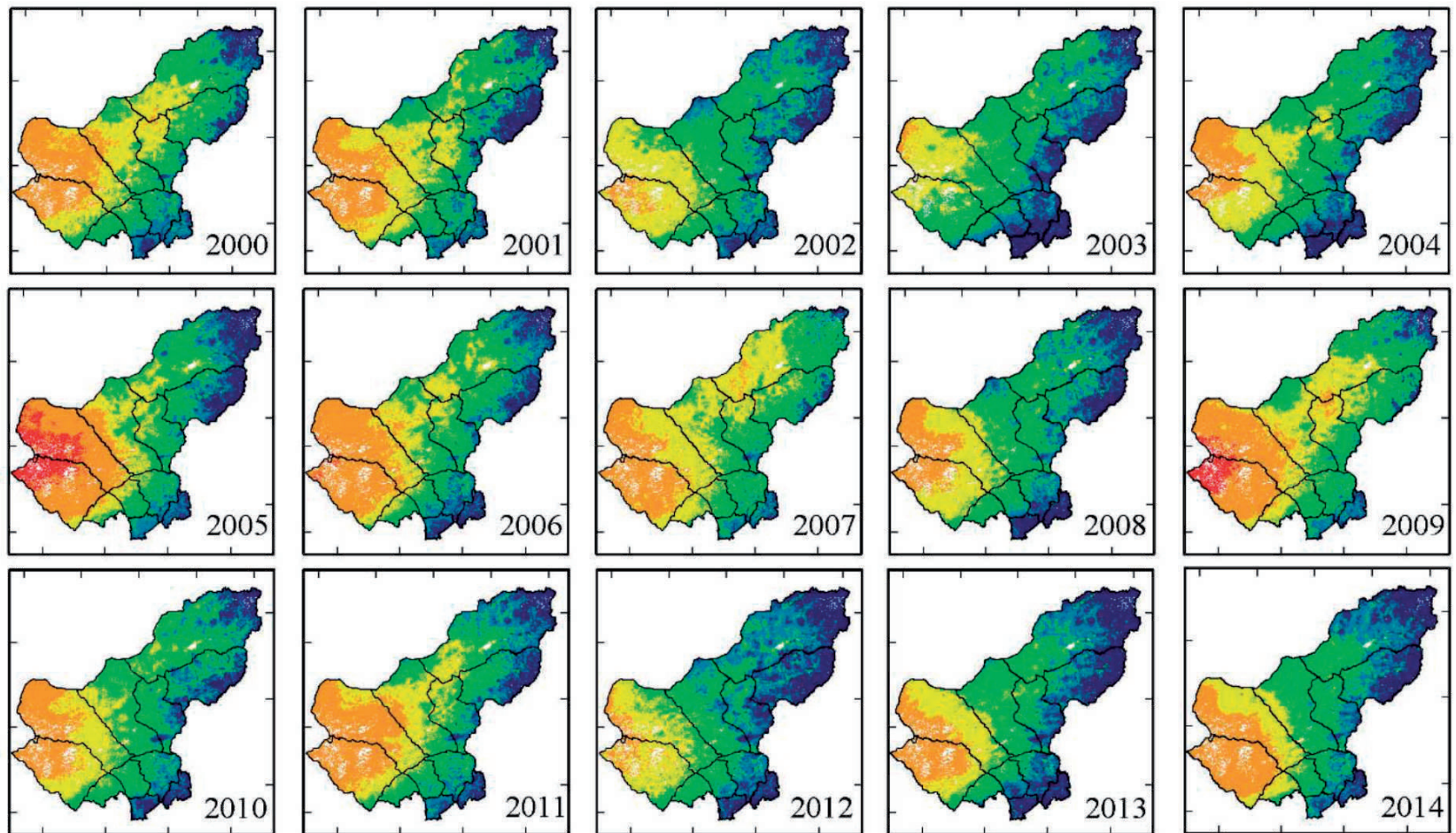

$\mathrm{ET} / \mathrm{mm}$

$<120 \square 120-150 \square 150-180 \square 180-250 \square 250-300 \square>300$
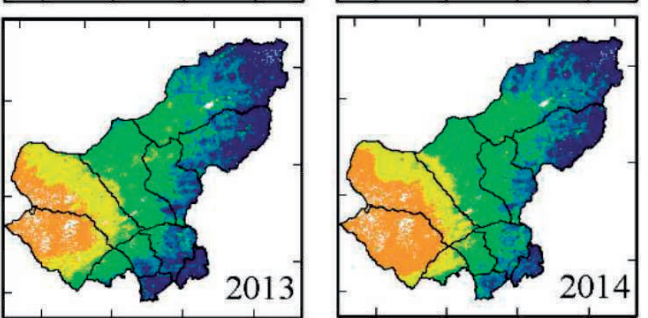

$0 \quad 250 \quad 500$

1,000

Fig. 4. Spatial distribution of the annual MODIS ET at the Xilingol steppe from 2000 to 2014.
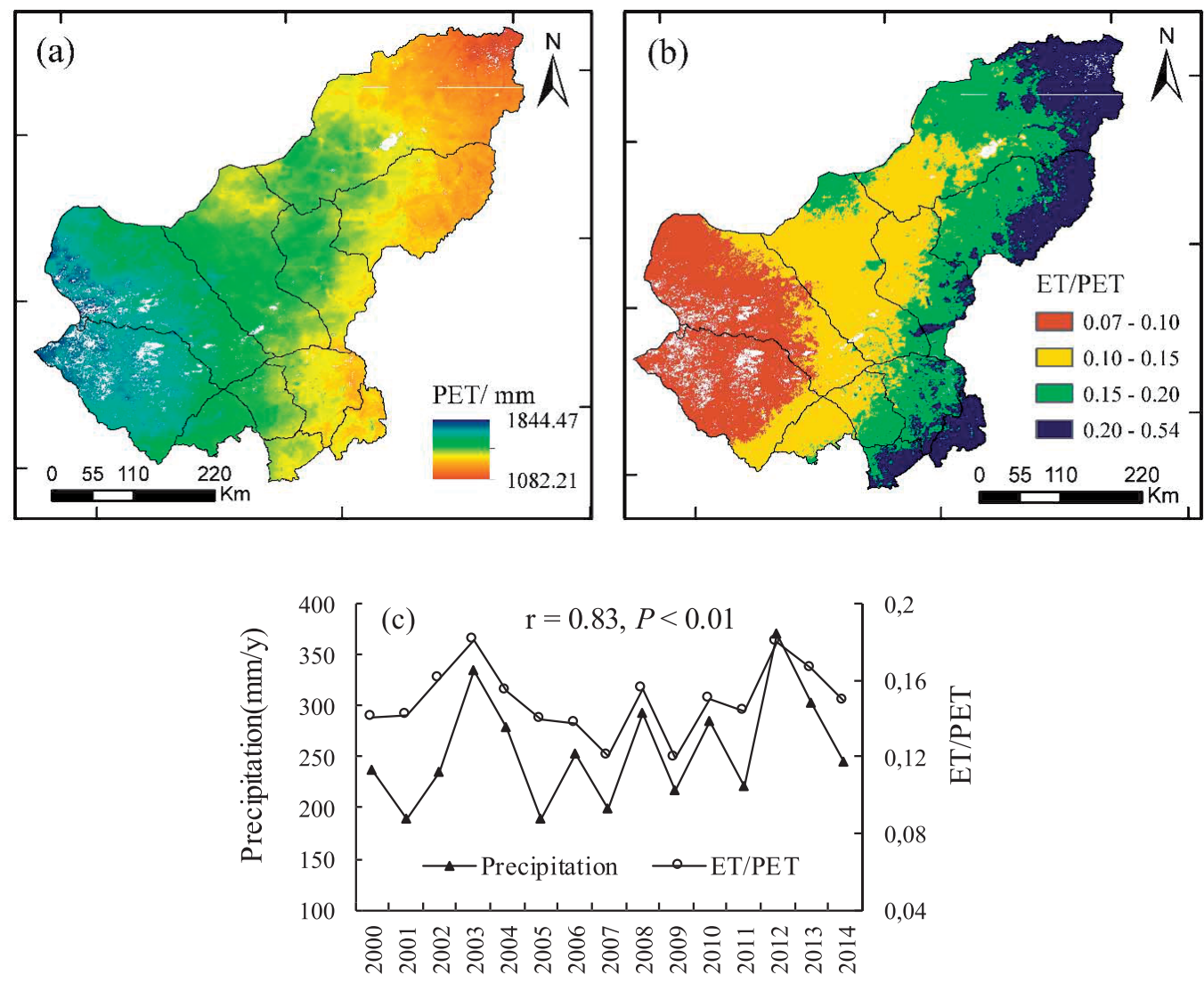

Year

Fig. 5. Spatial distributions of mean PET a) and mean $\frac{E T}{P E T}$ b), and curves of precipitation and $\frac{E T}{P E T}$ c) during 2000-2014 (PET data were generated from MOD16A2 product). 


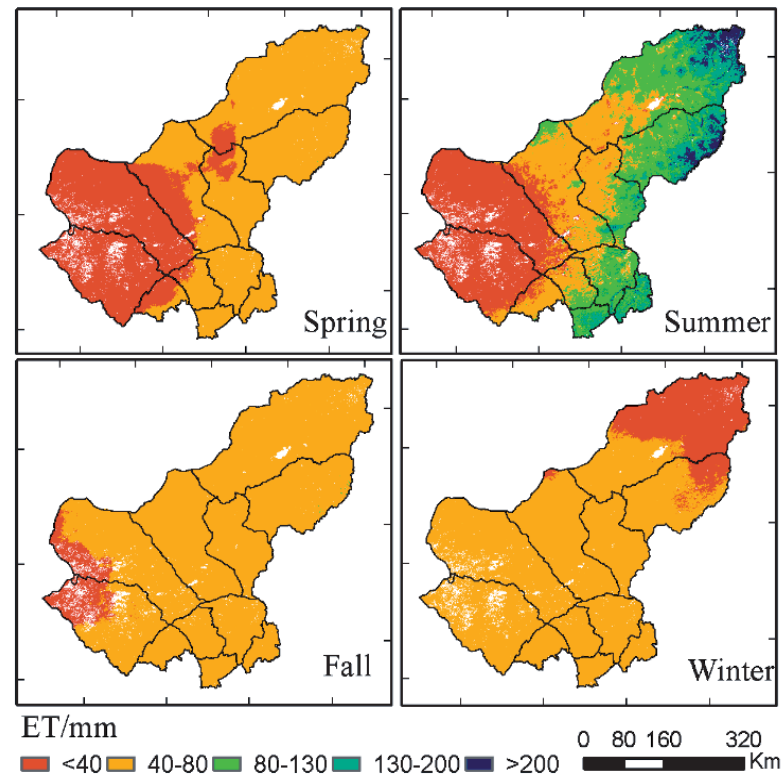

Fig. 6. Distribution of seasonally averaged ET during 2000-2014.

\section{Seasonal Variations in ET at the Xilingol Steppe}

Fig. 6 shows the spatial distribution of the seasonal ET. Consistent with the annual ET, the seasonally averaged ET value decreased from the northeast to the southwest in spring, summer and fall; however, in the winter, the ET value exhibited the opposite trend from the annual ET. Fig. 7 shows the seasonal ET changes in different grassland types during 2000-2014 and reveals that the ET in all grassland types showed similar fluctuation trends in each season. Except for two large values in the sandy vegetation in spring 2003 and fall 2010, ET in the spring, summer, and fall all showed the following order: meadow steppe>typical steppe and sandy vegetation>desert steppe; however, in the winter, ET followed the reverse order of desert steppe $>$ typical steppe and sandy vegetation>meadow steppe. In particular, the ET values in the whole Xilingol steppe were all close to that of the typical steppe and sandy vegetation in all four seasons.

In the spring (Fig. 7a), spatially averaged ET values in the meadow steppe, typical steppe, sandy vegetation, and desert steppe fluctuate around approximately $50 \mathrm{~mm}, 40 \mathrm{~mm}, 40 \mathrm{~mm}$, and $30 \mathrm{~mm}$, respectively, with similar fluctuation trends showing peaks in 2003, 2010, and 2013 and troughs in 2006 and 2009. In the summer (Fig. 7b), spatially averaged ET values in the meadow steppe, typical steppe, sandy vegetation, and desert steppe fluctuate around approximately $120 \mathrm{~mm}$, $60 \mathrm{~mm}, 60 \mathrm{~mm}$, and $20 \mathrm{~mm}$, respectively, and show similar fluctuation trends with peaks in 2003 and 2012. Additionally, during the fall (Fig. 7c), the spatially averaged ET values in the meadow steppe, typical steppe, sandy vegetation, and desert steppe fluctuate around approximately $60 \mathrm{~mm}, 50 \mathrm{~mm}, 50 \mathrm{~mm}$, and

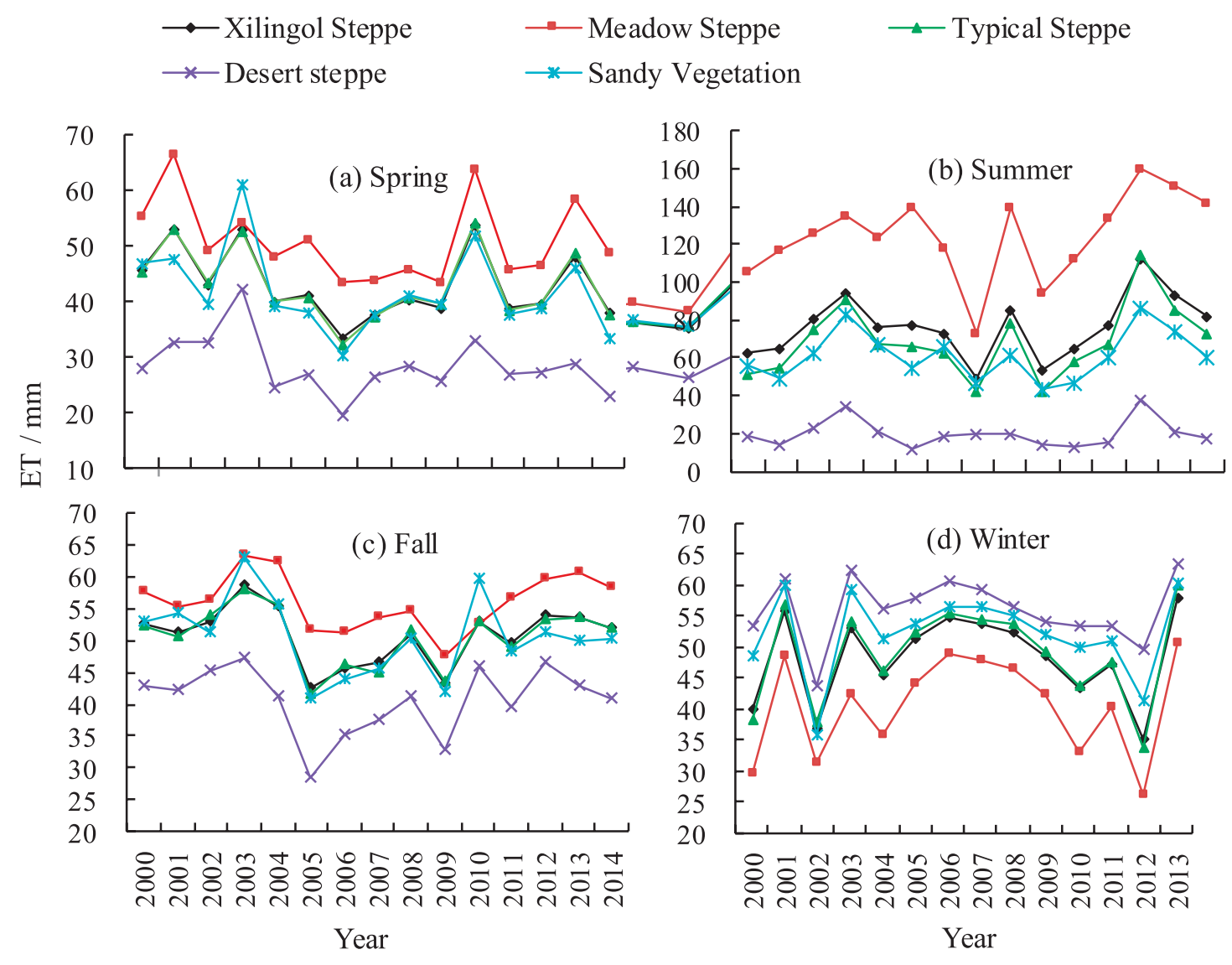

Fig. 7. Seasonal ET curves in different grassland types during 2000-2014. 
$40 \mathrm{~mm}$, respectively, with similar fluctuation trends showing peaks in 2003 and 2008 and troughs in 2005 and 2009. In the winter (Fig. 7d), spatially averaged ET values in the meadow steppe, typical steppe, sandy vegetation, and desert steppe fluctuate around approximately $40 \mathrm{~mm}, 50 \mathrm{~mm}, 50 \mathrm{~mm}$, and $55 \mathrm{~mm}$, respectively, and show similar fluctuation trends with peaks appearing in 2001, 2003, 2006 and 2011 and troughs in 2002, 2004, and 2012. A linear trend analysis showed that the ET in all grassland types showed decreasing trends in spring and fall and increasing trends in summer and winter, but none of the changes were significant $(P>0.05)$.

In general, the spatially averaged ET in the Xilingol steppe demonstrated the following order: summer $>$ fall $>$ winter $>$ spring, accounting for approximately $35 \%, 23 \%, 22 \%$, and $20 \%$ of the annual ET, respectively. The meadow steppe followed the order of summer $>$ fall $>$ spring $>$ winter, accounting for $46 \%, 20 \%, 19 \%$, and $15 \%$ of the annual ET, respectively. In the typical steppe the order was summer $>$ fall $>$ winter $>$ spring, accounting for $33 \%$, $24 \%, 23 \%$ and $20 \%$ of the annual ET, respectively. The sandy vegetation followed the order of summer $>$ fall and winter $>$ spring, accounting for $30 \%, 25 \%, 25 \%$ and $20 \%$ of the annual ET, respectively. The desert steppe followed the order of winter $>$ fall $>$ spring $>$ summer, accounting for $39 \%, 28 \%, 20 \%$ and $14 \%$ of the annual ET, respectively.

The opposite spatial distributions of ET in the growing season (including spring, summer and fall) and winter occur because the ET in the growing season is mainly due to the contribution of vegetation transpiration, where the greater the precipitation is, the better the vegetation grows, and the higher the vegetation transpiration is. Consequently, ET decreases from east to west in spring, summer and fall. However, in winter, vegetation withered and the transpiration nearly stopped in the Xilingol steppe, with most areas being covered by snow [35]. Therefore, ET is mainly due to the evaporation of soil and snow. Due to the low temperature in winter, the snow covering the ground hinders the evaporation of the soil, and the temperature in the southwest is higher than that in the northeast, leading to higher ET in the west than in the east. From these analyses, it can be inferred that the low annual precipitation (Fig. 2a) combined with high winter evaporation (Fig.7d) should be the main reasons for water scarcity in the western desert steppe [35, 43, 44], while the dry conditions of typical steppe and meadow steppe are probably caused by the uneven distribution of precipitation $[35,44]$ and high ET demands during the growing season.

\section{Relationships of ET with NDVI and Climate Parameters}

As shown in Figs 1, 2c) and 4, the annual ET and the growing seasonal NDVI have great consistency with the distribution of grassland types. Thus, the analysis was performed based on the whole Xilingol steppe instead of the different grassland types. Based on the weather station dataset with 225 samples (205 samples in winter), the relationships between ET and NDVI and climate parameters were investigated at the annual and seasonal scales.

\section{Annual Relationships of ET with NDVI and Climate Parameters}

Fig. 8(a-g) presents the scatter diagrams between the ET and NDVI and climate parameters at the annual scale, which shows that the determination coefficient is largest between ET and NDVI $(\mathrm{y}=694.73 \mathrm{x}+61.53$, $\left.\mathrm{R}^{2}=0.6845\right)$, followed by precipitation $(\mathrm{y}=0.42 \mathrm{x}$ $\left.+95.77, \mathrm{R}^{2}=0.5859\right)$, water vapor pressure $(\mathrm{y}=98.69 \mathrm{x}$ - 326.30, $\left.\mathrm{R}^{2}=0.5551\right)$ and relative humidity $(\mathrm{y}=6.41 \mathrm{x}$ - $\left.140.38, \mathrm{R}^{2}=0.4860\right)$ (Fig. $8(\mathrm{a}-\mathrm{d})$ ), with the correlation coefficients of $0.827,0.765,0.745$ and 0.697 , respectively (Table 2); all the linear equations and correlation coefficients are significant at the 0.01 level $(P<0.01)$. These results indicate that the annual ET is positively related to the vegetation growth, and precipitation is an important factor affecting the vegetation growth [45] and the ET process at the annual scale. Because the better vegetation growth generates more ET, the dry conditions in the central and eastern Xilingol are mainly caused by high ET demands and uneven precipitation distribution. Therefore, it is crucial for the healthy growth of vegetation to maintain a balance between precipitation and ET in arid and semiarid regions. In addition, the water vapor pressure and relative humidity are also positively related to ET and precipitation due to their interaction. These conclusions are consistent with the results of Zhao et al. [46] and Yang et al. [47], who showed that ET is highly positively correlated with NDVI and precipitation; as well as the results of Huang et al. [32] and Zhang et al. [33], who showed that the NDVI is mainly affected by precipitation with a strong positive correlation. Liu et al. [48] also showed that the change trend of NDVI is similar to that of ET at the annual scale in northern China.

Fig. 8(e-g) shows that ET exhibits extremely significant negative correlations $(P<0.01)$ with mean temperature $\left(\mathrm{y}=-14.51 \mathrm{x}+253.29, \mathrm{R}^{2}=0.1586\right)$, wind speed $\left(y=-33.60 x+319.40, R^{2}=0.1499\right)$ and sunshine hours $\left(\mathrm{y}=-0.12 \mathrm{x}+575.88, \mathrm{R}^{2}=0.1169\right)$. However, the effects of mean temperature, wind speed and sunshine hours on ET are relatively low with small determination coefficients and correlation coefficients (Table 2). The negative correlations of ET with mean temperature, wind speed and sunshine hours can be explained with the following reasons: 1) the latent heat accompanying the ET process has a cooling effect [5], 2) while vegetation growth requires certain temperature conditions, high temperature limits the vegetation growth as pointed out by Solangi et al. [49], 3) precipitation has great significance for water supply and 

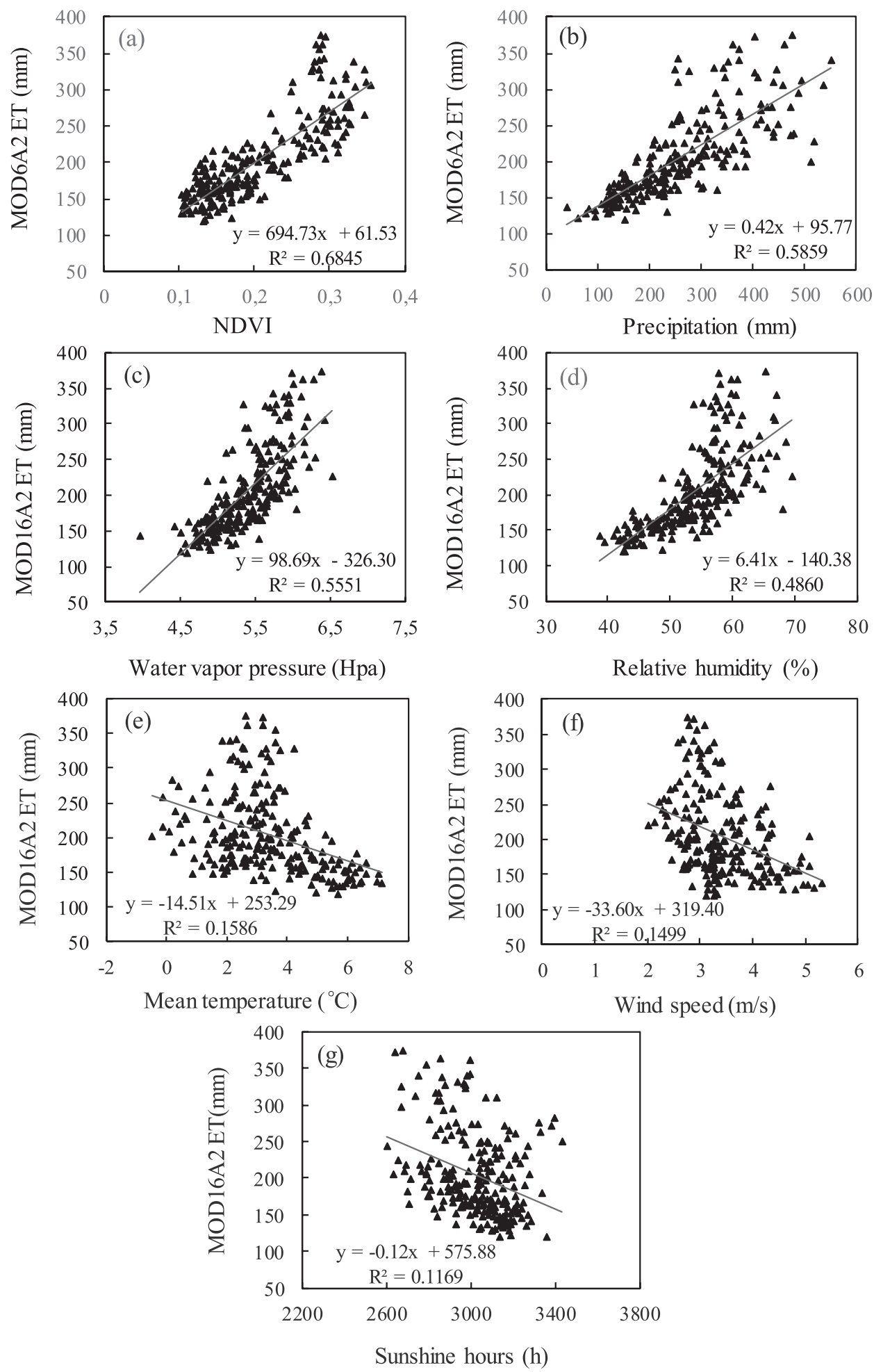

Fig. 8. Annual correlations between ET and NDVI and climate parameters during 2000-2014.

temperature regulation, and 4) sunshine and wind affect ET by affecting air temperature and stoma-closing.

\section{Seasonal Relationships of ET with NDVI and Climate Parameters}

Table 2 also shows that ET is positively correlated with NDVI, precipitation, relative humidity, and water vapor pressure at the 0.01 significant level in spring, summer, and fall (as shown in orange), while ET is negatively correlated with mean temperature, wind speed, and sunshine hours at the 0.01 significant level (as shown in green). In contrast, in winter, ET is negatively correlated with precipitation $(r=-0.480)$ and relative humidity $(r=-0.698)$ and positively correlated with mean temperature $(r=0.781)$, water vapor pressure 
Table 2. Pearson's correlation coefficients between ET and NDVI and climate parameters during 2000-2014.

\begin{tabular}{|c|c|c|c|c|c|c|c|}
\hline $\begin{array}{c}\text { Correlation } \\
\text { coefficients }\end{array}$ & NDVI & Precipitation & $\begin{array}{c}\text { Water vapor } \\
\text { pressure }\end{array}$ & $\begin{array}{c}\text { Relative } \\
\text { humidity }\end{array}$ & $\begin{array}{c}\text { Mean } \\
\text { temperature }\end{array}$ & Wind speed & $\begin{array}{c}\text { Sunshine } \\
\text { hours }\end{array}$ \\
\hline Spring & $0.622^{* *}$ & $0.598^{* *}$ & $0.669 * *$ & $0.810^{* *}$ & $-0.589 * *$ & $-0.388^{* *}$ & $-0.341^{* *}$ \\
\hline Summer & $0.837 * *$ & $0.674^{* *}$ & $0.641^{* *}$ & $0.831^{* *}$ & $-0.794 * *$ & $-0.582^{* *}$ & $-0.509 * *$ \\
\hline Fall & $0.476^{* *}$ & $0.506^{* *}$ & $0.381 * *$ & $0.582^{* *}$ & $-0.388^{* *}$ & $-0.244^{* *}$ & $-0.288^{* *}$ \\
\hline Winter & & $-0.480^{* *}$ & $0.492^{* *}$ & $-0.698^{* *}$ & $0.781^{* *}$ & $0.394 * *$ & $0.271^{* *}$ \\
\hline Annual & $0.827^{* *}$ & $0.765^{* *}$ & $0.745^{* *}$ & $0.697 * *$ & $-0.398^{* *}$ & $-0.387^{* *}$ & $-0.342^{* *}$ \\
\hline
\end{tabular}

Note: ** indicates significance at the $\mathrm{P}<0.01$ level.

$(r=0.492)$, wind speed $(r=0.394)$, and sunshine hours $(\mathrm{r}=0.271)$, and all the correlation coefficients are significant at the 0.01 level $(P<0.01)$.

As discussed in section 3.2, vegetation transpiration in spring, summer and fall has a large contribution to ET, as illustrated in Table 2, where ET and NDVI are positively correlated at the 0.01 significant level (Spring: $r=0.622$; Summer: $r=0.837$; Fall: $r=0.476$ ). Precipitation is the main water source and limiting factor for vegetation growth in this region [35, 45]. Many studies have shown that NDVI in the Xilingol steppe is mainly affected by precipitation, with a positive correlation coefficient of higher than 0.83 [32, 33]. Thus, the greater the precipitation is, the better the vegetation growth is and the higher the ET, water vapor pressure, and relative humidity are due to their interactions. Simultaneously, precipitation and ET result in a relatively low temperature, thus, ET in the growing season is negatively correlated with the mean temperature at the 0.01 significant level, as shown in Table 2 (Spring: $r=-0.589$; Summer: $r=-0.794$; Fall: $r=-0.388)$. However, the ET in winter mainly originates from snow and soil, and most areas of the Xilingol steppe are covered by snow in winter [35]. Therefore, the higher the temperature is, the more evaporation that will occur (Winter: $\mathrm{r}=0.781, P<0.01$ ). Consequently, the low annual precipitation combined with high winter evaporation is the main reason for the water scarcity in desert steppe.

Overall, the correlation between annual ET and various factors is highly consistent with the vegetation growing season (Spring-Fall), indicating that the factors influencing the annual ET are mainly determined by the vegetation growing season in the Xilingol steppe.

\section{Highest Partial Correlation Analysis between NDVI and ET and Climate Parameters}

To reveal the significance of ET to vegetation growth, the highest Pearson's partial correlation analysis was utilized to explore the direct relationships between NDVI and ET and climate parameters at both the annual and seasonal scales. Table 3 illustrates that NDVI has a relatively high correlation with ET and sunshine hours (as shown in green) but has low correlations with water vapor pressure, relative humidity, mean temperature and wind speed (as shown in orange), indicating that ET is a crucial factor that directly reflects vegetation growth; simultaneously, sunshine effectively promotes the photosynthesis process during vegetation growth. Precipitation and temperature, as well as other parameters, affect the vegetation growth by participating in the ET and photosynthesis processes instead of directly affecting the vegetation growth, and thus, these factors have low net correlation coefficients with NDVI.

In spring, the highest partial correlation coefficient between precipitation and NDVI is relatively high with the value of 0.305 at the 0.01 significant level (as shown in yellow in Table 3), indicating that precipitation in spring is essential for vegetation re-greening, while in the fall, the vegetation withered gradually, the NDVI decreases in the Xilingol steppe, and the ET mainly comes from soil evaporation. Therefore, the

Table 3. Highest partial correlation coefficients between NDVI and ET and other climate parameters.

\begin{tabular}{|c|c|c|c|c|c|c|c|}
\hline $\begin{array}{c}\text { Highest partial correlation } \\
\text { coefficients }\end{array}$ & ET & Precipitation & $\begin{array}{c}\text { Water vapor } \\
\text { pressure }\end{array}$ & $\begin{array}{c}\text { Relative } \\
\text { humidity }\end{array}$ & $\begin{array}{c}\text { Mean } \\
\text { temperature }\end{array}$ & $\begin{array}{c}\text { Wind } \\
\text { speed }\end{array}$ & $\begin{array}{c}\text { Sunshine } \\
\text { hours }\end{array}$ \\
\hline Spring & $0.368^{* *}$ & $0.305^{* *}$ & -0.053 & 0.038 & 0.012 & -0.079 & $0.361 * *$ \\
\hline Summer & $0.490^{* *}$ & 0.062 & -0.081 & 0.104 & 0.001 & 0.011 & $0.427 * *$ \\
\hline Fall & $0.166^{*}$ & 0.088 & 0.084 & 0.109 & -0.088 & $-0.173 *$ & $0.369 * *$ \\
\hline Annual & $0.661 * *$ & 0.128 & $-0.249 * *$ & $0.298^{* *}$ & 0.132 & 0.032 & $0.478^{* *}$ \\
\hline
\end{tabular}

Note: * and ** indicate significance at the $\mathrm{P}<0.05$ and $\mathrm{P}<0.01$ levels, respectively. 
highest partial correlation coefficient between NDVI and ET is low with the value of 0.166 at the 0.05 significant level.

Overall, NDVI is positively correlated with the annual ET $(r=0.661)$ and sunshine hours $(r=0.478)$ at the 0.01 significant level, indicating that ET and sunshine hours are the most direct factors involved in the vegetation growth process, which further strengthens the significance of monitoring and analyzing the ET variations in this region.

\section{Conclusions}

In this study, the MOD16A2 monthly product was utilized to reveal the spatiotemporal characteristics of actual ET at the annual and seasonal scales in Xilingol steppe. In the meantime, monthly MOD16A2 ET and MOD13A3 NDVI data, as well as meteorological data were used to analyze the relationships among ET, NDVI, and climate parameters. Based on analysis and discussion described above, this study has reached the following main conclusions: 1) the characteristics of actual ET is absolutely different from the pan evaporation measured at the weather station, 2) the annual ET decreased from northeast to southwest and fluctuated around approximately $200 \mathrm{~mm}$ during 2000-2014, 3) ET decreased from northeast to southwest in spring, summer and fall; however, in winter, ET increased from northeast to southwest, 4) ET in typical steppe, sandy vegetation and meadow steppe of the central and eastern Xilingol consumes more water in summer and fall than in winter and spring, while in the western desert steppe ET is the largest in the winter (accounting for 39\% of the annual ET), 5) precipitation and NDVI are decisive parameters positively affecting ET during the growing season, and mean temperature becomes a positively decisive parameter in winter, 6) since precipitation is the main water source, low annual precipitation combined with the high winter evaporation might be the main reason for the dry condition in the western desert steppe, and 7) uneven distributions of precipitation combined with high growing season ET demands should be the main reason for the dry conditions in the central and eastern Xilingol. The findings of this study are of great significance for better understanding and assessing the dry conditions and drought events.

Due to the unavailability of the monthly MOD16A2 after 2014, this study didn't analyze the ET variations in recent years, which should be continuously studied in the future by using MOD16A2 8-day product. In addition, the multi-variable regression between ET and various parameters and the application of ET in drought monitoring are worthy of further study.

\section{Acknowledgments}

This study was supported by the China National Scholarship Council Project (201908150028), the National Natural Science Fund of China (41661009) and the Talent Fund of Inner Mongolia Normal University (2016YJRC012).

\section{Conflicts of Interest}

The authors declare that they have no conflicts of interest.

\section{References}

1. HANSON R.L. Evapotranspiration and droughts. National Water Summary 1988-89: Hydrologic Events and Floods and Droughts (US Geological Survey Water-Supply Paper 2375), 99, 1991.

2. ALLEN R.G., PEREIRA L.S., RAES D., SMITH M. Crop Evapotranspiration - Guidelines for Computing Crop Water Requirements. FAO Irrigation and drainage paper 56. Fao, Rome, 300 (9), D05109, 1998.

3. LI Z., TANG R., WAN Z., BI Y., ZHOU C., TANG B., YAN G., ZHANG X. A review of current methodologies for regional evapotranspiration estimation from remotely sensed data. Sensors, 9 (5), 3801, 2009. DOI:10.3390/ s90503801

4. TRENBERTH K.E., FASULLO J.T., KIEHL J. Earth's global energy budget. Bulletin of the American Meteorological Society, 90 (3), 311, 2009.

5. JUNG M., REICHSTEIN M., CIAIS P., SENEVIRATNE S.I., SHEFFIELD J., GOULDEN M.L., BONAN G., CESCATTI A., CHEN J., DE JEU R., DOLMAN A.J., EUGSTER W., GERTEN D., GIANELLE D., GOBRON N., HEINKE J., KIMBALL J., LAW B.E., MONTAGNANI L., MU Q., MUELLER B., OLESON K., PAPALE D., RICHARDSON A.D., ROUPSARD O., RUNNING S., TOMELLERI E., VIOVY N., WEBER U., WILLIAMS C.,WOOD E., ZAEHLE S., ZHANG K. Recent decline in the global land evapotranspiration trend due to limited moisture supply. Nature, 467 (7318), 951, 2010. DOI: $10.1038 /$ nature 09396 - Source: PubMed

6. KOSTE R.D., DIRMEYER P.A., GUO Z., BONAN G., CHAN E., COX P., GORDON C.T., KANAE S., KOWALCZYK E., LAWRENCE D., LIU P., LU C., MALYSHEV S., MCAVANEY B., MITCHELL K., MOCKO D., OKI T., OLESON K., PITMAN A., SUD Y. C., TAYLOR C.M., VERSEGHY D., VASIC R., XUE Y., YAMADA T. Regions of strong coupling between soil moisture and precipitation. Science, 305 (5687), 1138, 2004.

7. OKI T., KANAE S. Global hydrological cycles and world water resources. Science, 313 (5790), 1068, 2006. DOI:10.1126/science. 1128845

8. ABDULRAZZAQ Z.T., HASAN R.H., AZIZ N.A. Integrated TRMM Data and Standardized Precipitation Index to Monitor the Meteorological Drought. Civil Engineering Journal, 5 (7), 1590, 2019. DOI: http://dx.doi. org/10.28991/cej-2019-03091355 
9. ALI A., PASHA G.A., GHANI U., AHMED A., ABBAS F.M. Investigating Role of Vegetation in Protection of Houses during Floods. Civil Engineering Journal, 5 (12), 2598, 2019. DOI: http://dx.doi.org/10.28991/cej-201903091436

10. ARYAL K., THAPA P.S., LAMICHHANE D. Revisiting Agroforestry for Building Climate Resilient Communities: A Case of Package-Based Integrated Agroforestry Practices in Nepal. Emerging Science Journal, 3 (5), 303, 2019. DOI: http://dx.doi.org/10.28991/esj-2019-01193

11. WANG X., DONG J., BAOYIN T., BAO Y. Estimation and Climate Factor Contribution of Aboveground Biomass in Inner Mongolia's Typical/Desert Steppes. Sustainability, 11 (23), 6559, 2019. DOI:10.3390/su11236559

12. WU J., NAEEM S., ELSER J., BAI Y., HUANG J., KANG L., PAN Q., WANG Q., HAO S., HAN X. Testing biodiversity-ecosystem functioning relationship in the world's largest grassland: overview of the IMGRE project. Landscape Ecology, 30 (9), 1723, 2015. DOI: 10.1007/ s10980-015-0155-y

13. TONG S., LI X., ZHANG J., BAO Y., BAO Y., NA L., SI A. Spatial and temporal variability in extreme temperature and precipitation events in Inner Mongolia (China) during 1960-2017. Science Total Environment, 649, 75, 2019. DOI: https://doi.org/10.1016/j.scitotenv.2018.08.262

14. ZHANG Q., LIU G., YU H., BAO Y. Analysis of drought characteristics in Xilingol League based on Standardized precipitation index. Journal of natural disasters, 25 (5), 119, 2015 [In Chinese].

15. BATUNACUN, WIELAND R., LAKES T., YUNFENG H., NENDEL C. Identifying drivers of land degradation in Xilingol, China, between 1975 and 2015. Land Use Policy, 83, 543, 2019. DOI: https://doi.org/10.1016/j. landusepol.2019.02.013

16. XU G., KANG M., METZGER M., JIANG Y. Vulnerability of the Human-Environment System in Arid Regions: The Case of Xilingol Grassland in Northern China. Polish Journal of Environmental Studies, 23 (5), 1773, 2014.

17. WANG Y., ZHANG K., LI F. Monitoring of fractional vegetation cover change in Xilingol League based on MODIS data over 10 years. Journal of Arid Land Resources and Environment, 9, 165, 2012 [In Chinese].

18. LI X., LI G., WANG H., WANG H., YU J. Influence of meadow changes on net primary productivity: a case study in a typical steppe area of XilinGol of Inner Mongolia in China. Geosciences Journal, 19 (3), 561, 2015. DOI: 10.1007/s12303-014-0057-z

19. SCHAFFRATH D., BERNHOFER C. Variability and distribution of spatial evapotranspiration in semi arid Inner Mongolian grasslands from 2002 to 2011. SpringerPlus, 2 (1), 547, 2013.

20. PENMAN H.L. Natural evaporation from open water, hare soil and grass. Proceedings of the Royal Society of London. Series A,Mathematical and physical sciences, 193 (1032), 120, 1948

21. MONTEITH J.L. Evaporation and environment, In Symposia of the society for experimental biology, Cambridge University Press (CUP): Cambridge, England. 205, 1965.

22. ROERINK G.J., SU Z., MENENTI M. S-SEBI: A Simple Remote Sensing Algorithm to Estimate the Surface Energy Balance. Physics and Chemistry of the Earth, Part B: Hydrology, Oceans and Atmosphere, 25 (2), 147, 2000. DOI:10.1016/S1464-1909(99)00128-8
23. BASTIAANSSEN W.G., MENENTI M., FEDDES R., HOLTSLAG A. A remote sensing surface energy balance algorithm for land (SEBAL). 1. Formulation. Journal of hydrology, 212, 198, 1998a.

24. BASTIAANSSEN W.G., PELGRUM H., WANG J., MA Y., MORENO J., ROERINK G., VAN DER WAL T. A remote sensing surface energy balance algorithm for land (SEBAL): Part 2: Validation. Journal of hydrology, 212, 213, 1998 b.

25. SU Z. The Surface Energy Balance System (SEBS) for estimation of turbulent heat fluxes. Hydrology and Earth System Sciences, 6 (1), 85, 2002. DOI: 10.5194/hess-6-852002

26. ZHANG K., KIMBALL J. S., RUNNING S. W. A review of remote sensing based actual evapotranspiration estimation. Wiley Interdisciplinary Reviews: Water, 3 (6), 834, 2016. DOI:https://doi.org/10.1002/wat2.1168

27. FAN J., LI D., GAO M. Spatio-temporal Variations of Evapotranspiration in Shanxi Province Using MOD16 Products. Ecology and Environmental Sciences, 23 (9), 1536, 2014 [In Chinese].

28. ALEMU H., SENAY G., KAPTUE A., KOVALSKYY V. Evapotranspiration Variability and Its Association with Vegetation Dynamics in the Nile Basin, 2002-2011. Remote Sensing, 6 (7), 5885, 2014. DOI:10.3390/rs6075885

29. ADILAI W., YUSUFUJIANG R., REYILAI K., JIANG H. Spatio-temporal distribution and evolution trend of evapotranspiration in Xinjiang based on MOD16 data. Geographical Research, 36 (7), 1245, 2017 [In Chinese].

30. BOARD E., The Xilingol League history: Part I. In Inner Mongolia People's Publishing House: Hohhot, China, 1996 [In Chinese].

31. BOARD E. Geography Volume. In Encyclopedia of Mongolian Science. Inner Mongolia People's Publishing House: Hohhot, China, 183, 2012 [In Chinese].

32. HANG Y., BAO G., BAO Y., BURENJIRIGALA, DORJSUREN A. Spatiotemporal Changes of Vegetation Coverage in Xilin Gol Grassland and Its Responses to Climate Change during 2000-2010. Acta Agrestia Sinica, 22 (6), 1194, 2014 [In Chinese].

33. ZHANG S., ZHAO H., ZHANG F., SHANG S. Temporal and spatial dynamic of Xilingol steppe based on MODIS NDVI in recent ten years. Pratacultural Science, 8 (8), 1416, 2014 [In Chinese].

34. DWYER J., SCHMIDT G. The MODIS reprojection tool. In Earth science satellite remote sensing; Qu J.J., Gao W., Kafatos M., Murphy R.E., Salomonson V.V., Eds.,Springer, Berlin, Germany, 162, 2006.

35. TONG S., BAO Y., TE R., MA Q., HA S., LUSI A. Analysis of Drought Characteristics in Xilingol Grassland of Northern China Based on SPEI and Its Impact on Vegetation. Mathematical Problems in Engineering, 2017, 1-11, 2017. DOI: https://doi.org/10.1155/2017/5209173

36. OBILOR E.I., AMADI E. Test for Significance of Pearson's Correlation Coefficient ( ). International Journal of Innovative Mathematics, Statistics \& Energy Policies, 6 (1), 11, 2018.

37. ZHANG G., XU X., ZHOU C., ZHANG H., OUYANG H. Responses of grassland vegetation to climatic variations on different temporal scales in Hulun Buir Grassland in the past 30 years. Journal of Geographical Sciences, 21 (4), 634, 2011. DOI: 10.1007/s11442-011-0869-y

38. CHEN Y., XIA J., LIANG S., FENG J., FISHER J.B., LI X., LI X., LIU S., MA Z., MIYATA A., MU Q., SUN L., TANG J., WANG K., WEN J., XUE Y., YU G., ZHA T., 
ZHANG L. ZHANG Q., ZHAO T., ZHAO L. YUAN W. Comparison of satellite-based evapotranspiration models over terrestrial ecosystems in China. Remote Sensing of Environment, 140, 279, 2014. DOI: http://dx.doi. org/10.1016/j.rse.2013.08.045

39. WU H., XIONG D., LIU B., ZHANG S., YUAN Y., FANG Y., CHIDI C. L., DAHAL N. M. Spatio-Temporal Analysis of Drought Variability Using CWSI in the Koshi River Basin (KRB). Int J Environ Res Public Health, 16 (17), 3100, 2019. DOI:10.3390/ijerph 16173100

40. BAI J., YU Y., DI L. Comparison between TVDI and CWSI for drought monitoring in the Guanzhong Plain, China. Journal of Integrative Agriculture, 16 (2), 389, 2017. DOI: $10.1016 /$ S2095-3119(15)61302-8

41. TONG S., ZHANG J., BAO Y. Inter-decadal Spatiotemporal Variations of Aridity Based on Temperature and Precipitation in Inner Mongolia, China. Polish Journal of Environmental Studies, 26 (2), 819, 2017. DOI: $10.15244 /$ pjoes $/ 65840$

42. ZHANG Q., LIU G., YU H., YUSHAN, BAO Y. Soil moisture modelling and drought monitoring using remote sensing in Xilingol grassland. Acta Prataculturae Sinica, 26 (11), 1, 2017 [In Chinese].

43. ZHANG Q. Study on Drought Disaster Monitoring and Risk Assessment in Xilingol Grassland. Chinese Academy of Agricultural Sciences, 2016 [In Chinese].

44. MA Q., ZHANG J., SUN C., ZHANG F., WU R., WU L. Drought characteristics and predictio during pasture growing season in Xilingol grassland, northern China. Theoretical and Applied Climatology, 133 (1-2), 165, 2017. DOI: 10.1007/s00704-017-2150-5

45. TONG S., ZHANG J., HA S., LAI Q., MA Q. Dynamics of Fractional Vegetation Coverage and Its Relationship with Climate and Human Activities in Inner Mongolia, China. Remote Sensing, 8 (9), 776, 2016. DOI:10.3390/rs8090776

46. ZHAO J., CHEN X., ZHANG J., ZHAO H., SONG Y. Higher temporal evapotranspiration estimation with improved SEBS model from geostationary meteorological satellite data. Scientific reports, 9 (1), 14981, 2019. DOI: https://doi.org/10.1038/s41598-019-50724-w

47. YANG Z., ZHANG Q., HAO X. Evapotranspiration Trend and Its Relationship with Precipitation over the Loess Plateau during the Last Three Decades. Advances in Meteorology, 2016, 1, 2016. DOI:http://dx.doi. org/10.1155/2016/6809749

48. LIU J., XIONG Y., TIAN J., TAN Z. Spatiotemporal Changes in Evapotranspiration from an Overexploited Water Resources Basin in Arid Northern China and Their Implications for Ecosystem Management. Sustainability, 11 (2), 445, 2019. DOI:10.3390/su11020445

49. SOLANGI G. S., SIYAL A. A., SIYAL P. Spatiotemporal Dynamics of Land Surface Temperature and Its Impact on the Vegetation. Civil Engineering Journal, 5 (8), 1753, 2019. DOI: http://dx.doi.org/10.28991/cej-2019-03091368 